lying about for twelve hours. I think it would have been much more discourteous to the King to have kept his message waiting for a day than it was to send it by cable."

It seems, therefore, that the King, having sent his reply to the $I$.ondon office of the IVireless Telegraph Company, the company could not send it on to Poldhu for transmission to America on account of the fact that it was impossible at night to wire from London to Poldhu: thev were compelled, in consequence, to send the message by cable, the cable companies possessing the advantage: of a direct connection between the Post Office lines and the shore ends of their cables. It is a similar connection for which the Marconi Company asks and offers to pay, but which the Post Office declines to grant.

In these circumstances it is not surprising that $\mathrm{Mr}$. Marconi's feelings towards the Post Office are rather bitter, and that he proposes to make no further additions to the Poldhu Station until the authorities have decided what they intend to do. He now proposes to go to Italy and build a huge station there, probably at Rome, partly, no doubt, because, as he says, "Abroad I can get everything I want. Here in England I can get nothing." "This is a little sweeping, for all England has not been so backward in supporting Mr. Marconi's enterprise as the officials of the Post Office. The attitude of the Post Office, however, certainly seems inexcusable, and we do not see by what reasonable arguments it can be supported. It has been urged that, until Mr. Marconi has been able to convince a jury of Government officials and independent experts that his system is capable of satisfying stringent tests of trustworthiness for a definite period under definite conditions, the Post Office is fully justified in withholding its recognition and support. This argument seems to us unsound. If the Post Office is not satisfied that Transatlantic wireless telegraphy is trustworthy, let it, by all means, send its own messages by cable; but is this any reason why the man in the street-or the King-who wishes to benefit by any advantages in tariff or otherwise, which the Marconi Company may offer, and who is willing to run the risk of his message getting lost on the way, or read by Mr. Maskelyne at Porthcurnow, should be denied the necessary facilities? Or is it any reason why the more enlightened Governments of Canada and the Lnited States should be penalised by having their messages delayed, as we suppose must now occur if they arrive by night?

It seems to us that the correct thing for the Post Office to do is to grant the Wircless Telegraph Co. the facilities for which it asks without delay, lest the Post Office be accused, with some justice, of blocking the progress of an enterprise of great promise. Whether Transatlantic wireless telegraphy will prove of commercial value or not time will show; the shareholders may be relied upon to put an end to it soon enough if it neither pays nor gives prospect of paying. Should it, as some sanguine people think, prove better than the submarine cable, and ultimately supplant it, the cable companies will have to suffer that the world at large may gain; it will not be the first time in history that the old order has given place to the new. But none of these questions, commercial or technical, secms to us to be the concern of the Post Office, which should only desire to facilitate a new means of communication in which, rightly or wrongly, a large portion of the general public have considerable confidence.

In the meantime, the development of wireless telegraphy progresses rapidly in other directions, and especially in the direction in which we have always maintained it would be most serviceable, namely, in increasing the safety and relieving the monotony of travelling by sea. Reports are continually appearing in the papers of ships communicating with one another, or with the shore, for sone time prior to their arrival. Reuter's Agency has been experimenting in transmitting news to ships, and last week the Minneapolis, thirty-six hours before its arrival, was put in possession of all the latest news, much to the satisfaction of the passengers. Reuter's Agency, it is said, looks forward to the time when it will be able to maintain a daily news service right across the Atlantic. The day is possibly not far distant when it will be possible for all ships to keep in constant communication with land. and if this result is attained, wireless telegraphy will have scored a great and lasting success; but to derive the greatest benefit from such an achievement in this, as in the Transatlantic service, the Post Office must cooperate and not oppose progress. We trust someone will ask Mr. Ballour if it is the intention of the Government to bar all scientific progress.

MaLrice Solomon.

\section{THE CONSTITUTION OF THE NEW EDUCATION COMMITTEES.}

VARIOUS applications have been made to the Board of Education for suggestions with respect tn the constitution of education committees under the new Education Act, and the framing of schemes for the purpose. With a view to assist councils who have not as yet framed schemes for themselves and desire assistance, the Board of Education issued on February I 2 a memorandum making suggestions as to the main matters which should be provided for by the scheme. The Act itself lays it down that every scheme shall provide for the appointment by the council of at least a majority of the committee, and the persons so appointed shall be persons who are members of the council, unless, in the case of a county, the council shall otherwise determine; for the appointment by the council, on the nomination or recommendation, where it appears desirable, of other bodies (including associations of voluntary schools), or persons of experience iil education, and of persons acquainted with the needs of the various kinds of schools in the area for which the council acts; for the inclusion of women, as well as men, among the members of the committee; and for the appointment, if desirable, of members of school boards existing at the time of the passing of the Education Act as members of the first committee.

The memorandum referred to contains a model scheme, which goes a long way towards elucidating what, in the opinion of the Board of Education, is to be understood exactly by the words " nomination or recommendation " in the Act. This part of the model scheme reads as follows:-

Nominated members, one nominated by each of the following bodies, e.g.:--

The

council of the University of

Recommended members, one recommended by each of the following bodies, e.g. :-

The Chamber of Conmerce of

The Agricultural Society of

The Association of

The Governing Body of the

An electing body consisting of

Members appointed after consultation with :- -

The

It is of great importance that the Board of Education appears to contemplate that the right of nomination will belong to universities alone, while other associations and institutions can merely recommend persons for appointment by the council. Moreover, the memorandum refers to the representation of the interests of University education, and as we believe this is the first time in which the work of Universities has been mentioned as coming within the sphere of the Act, it is important to direct particular attention to this point. 
The reference to University education occurs in the part of the memorandum which interprets what is meant by the words" persons of experience in education and of persons acquainted with the needs of the various kinds of schools." The interests which are always to be represented either among the members appointed from the council or among members appointed from outside the council are thus enumerated :- University education; the secondary education of boys and girls in its higher and lower grades; technical instruction and commercial and industrial education, having special regard to the industries of a particular district; the training of teachers; and elementary education in council schools and in voluntary schools.

The Board of Education evidently does not intend that the councils concerned with the appointment of education committees shall be allowed to lose sight of the needs of higher and secondary education. It is earnestly to be desired that men of science in all parts of the country will be willing to become members of these education committees, so that councils everywhere may be kept informed as to what must be done if. as a nation, we are to make up the lecway in our educational affairs as compared with those of, say, Germany and the United States.

\section{NOTES.}

THE Bakerian lecture of the Royal Society on Thursday next, February 26, will be delivered by Mr. C. T. Heycock, F.R.S., and Mr. F. H. Neville, F.R.S., on "Solid Solution and Chemical Transformation in the Bronzes."

WE regret to see the announcement that Mr. F. C. Penrose, F.R.S., died on Sunday last at the age of eighty-five. From an obituary notice in the Times we learn that Mr. Penrose was born at Bracebridge, near Lincoln, and, after four years at Bedford Grammar School, entered the foundation at Winchester College. At Cambridge he was a senior optime in the Mathematical Tripos in 1842 , and for three years thereafter he held the appointment of Travelling Bachelor to the University. In 18,5 he brought out, for the Society of Dilettanti, a work entitled "The P'rinciples of Athenian Architecture," of which a second edition has been published. In the following ycar he was appointed Surveyor of the Fabric of St. Paul's Cathedral, a post which he held until 1897 . He published in 1860 " $\Lambda$ Method of Predicting Occultations of Stars and Solar Eclipses by Graphical Construction," of which a new edition was issued last year; and during 1893 he contributed to the Transactions of the Royal Society a paper on the astronomical significance of the orientation of Greek temples, which was followed by a supplement on the same subject in 1897 . His last work was an endeavour to determine the age of Stonehenge by utilising the orientation theory combined with accurate measurement of the direction of the axis of the building. It is rarely that the scientific and artistic temperaments are found so closely united in one man. His death is a loss both to science and art, which will be widely felt.

At the Cambridge Philosophical Society on February 2, the president, Dr. Baker, proposed from the chair, "That the Cambridge Philosophical Society desires to express its sense of the great loss sustained by the University and the Society in the death of Sir George Gabrinl Stokes, to whom the Society was bound by so many ties of obligation and reverence." This was seconded by Prof. Thomson, and carried unanimously. The Society then adjourned, as a mark of respect to Stokes's memory.

AT a conference of botanists of Vienna held on December 9 , 1902, the organising committce was elected for the InterNo. 1738 , vOL. 67$]$ national Botanical Conference which is to be held at Vienna in 1905. The officers of the committee are as follows:Honorary presidents: Dr. Guillaume de Hartel, Minister of Public Instruction; Dr. Charles de Giovanelli, Minister of Agriculture; Prof. Edouard Suess. Presidents: Prof. Richard de Wettstein and Prof. Jules Wiesner. Vice-presidents: Prof. Edouard Yackel and Prof. Hans Molisch. General secretary: Dr. Alexander Zahlbruckner. Secretaries: Dr. Charles Linsbauer and Dr. Frédéric Vierhapper. Treasurer : Dr. Léopolde de Portheim. All communications concerning the congress should be addressed to the general secretary, Dr. A. Zahlbruckner, Vienne, I., Burgring 7 .

THE biennial Hunterian Oration was delivered on the afternoon of February 14 by Sir Henry Howse, president of the Royal College of Science, in the theatre of the college. He devoted the greater part of his oration to interesting biographical incidents concerning John Hunter, who was elected a fellow of the Royal Society in 1767 , and appointed surgeon-extraordinary to the $\mathrm{King}$ in 1776 . The collection of the objects in his museum was Hunter's chief interest through many years of his life, and at his death there were 14,000 specimens in the museum, on which Hunter spent $70,000 l$. A banquet took place in the evening in the library of the college, at which the honorary fellowship of the college was conferred on Lord Roberts, who, in his reply, referred to the outbreaks of enteric fever at Bloemfontein and Kroonstad during the late war, and expressed his admiration for the way in which the medical officers managed to meet all emergencies with a minimum of appliances.

THE Rumford Committee of the American Academy of Arts and Sciences has madc the following grants in aid of investigations in light and heat :--250 dollars to Dr. Ralph S. Minor, of Little Falls, N. Y., for a research on the dispersion and absorption of substances for ultra-violet radiation; roo dollars to Dr. Sidney D. Townley, of Berkeley, Cal., for the construction of a stellar photometer of a type devised by Prof. E. C. Pickering and already in use in the study of the light of variable stars; 200 dollars to Prof. Edwin B. Frost, for the construction of a special lens for use in connection with the stellar spectrograph of the Yerkes Observatory to aid in the study of the radial velocities of faint stars; 250 dollars to Profs. E. F. Nichols and G. F. Hull, of Dartmouth College, for their research on the relative motion of the earth and the ether; 300 dollars to Prof. G. E. Hale, of the Yerkes Observatory, for the purchase of a Rowland concave grating to be used in the photographic study of the spectra of the brightest stars.

$\Delta \mathrm{T}$ a meeting of the Royal Commission for the Exhibition of 1851 , held on Februaly 10 , the Prince of Wales was unanimously elected president of the Commission in succession to His Majesty the King, who had held that position since the year 1870 . In taking the chair, the Prince of Wales remarked :- "The history of the Commission seems a somewhat curious one. Originally appointed merely to rarry nut the great Exhibition of $185 \mathrm{r}$, it was afterwards charged with the duty of disposing of the sum of $180,000 l$. the profit resulting from that Exhibition, a task which, in ordinary circumstances, might have been speedily completed. But the happy investment of the bulk of the money in the Kensington Gore estate gave the Commission a permanent character. The acquisition of the estate and its subsequent great increase in value has enabled the Com. missioners to afford considerably more help in the promotion of science and the arts than could have bcen anticipated from the sum of money originally at their disposal. Without going into detail, the Commissioners are aware that 